\title{
Identification of the Kainate Receptor Subunits Underlying Modulation of Excitatory Synaptic Transmission in the CA3 Region of the Hippocampus
}

\author{
Anis Contractor, ${ }^{1}$ Geoffrey T. Swanson, ${ }^{1}$ Andreas Sailer, ${ }^{1}$ Stephen O'Gorman, ${ }^{2}$ and Stephen F. Heinemann ${ }^{1}$ \\ ${ }^{1}$ Molecular Neurobiology Laboratory and ${ }^{2}$ Gene Expression Laboratory, The Salk Institute for Biological Studies, La Jolla, \\ California 92037
}

To understand the physiological role of kainate receptors and their participation in seizure induction in animal models of epilepsy, it will be necessary to develop a comprehensive description of their action in the CA3 region of the hippocampus. Activation of presynaptic kainate receptors depresses excitatory synaptic transmission at mossy fiber and associationalcommissural inputs to CA3 pyramidal neurons (Vignes et al., 1998; Bortolotto et al., 1999; Kamiya and Ozawa, 2000). In this study, we use gene-targeted mice lacking glutamate receptor 5 (GluR5) or GluR6 kainate receptor subunits to identify the receptor subunits that comprise the kainate receptors responsible for presynaptic modulation of CA3 transmission. We found that bath application of kainate $(3 \mu \mathrm{M})$ profoundly reduced EPSCs at mossy fiber and collateral synapses in neurons from wild-type

Kainate receptor subunits comprise a family of channel-forming glutamate receptors known to be involved in the induction of seizure behavior in the hippocampus (Ben-Ari, 1985; Mulle et al., 1998), but whose physiological function and spectrum of activities are just beginning to be understood. Central excitatory synaptic transmission is mediated predominantly by ionotropic glutamate receptors composed of either NMDA or AMPA receptor subunits (Hollmann and Heinemann, 1994; Dingledine et al., 1999). The contribution of these receptors to brain function has been well characterized because of their prominent roles in synaptic transmission and the availability of selective agonists and antagonists. In contrast, kainate receptors seem to have more subtle roles in modulating neurotransmission and contribute modestly to some EPSCs. The advent of pharmacological tools and the generation of knock-out mice lacking kainate receptor subunits have produced an understanding of the neurophysiology of these receptors, but a consensus as to their primary role in the brain has been slower to develop (Chittajallu et al., 1999; Frerking and Nicoll, 2000).

Kainate receptors are localized to both presynaptic and postsynaptic sites in the hippocampus. Kainate-mediated EPSCs have been characterized at the mossy fiber (MF) synapse onto CA3 pyramidal neurons and at pyramidal cell inputs to CA1 interneurons (Castillo et al., 1997; Vignes and Collingridge, 1997; Cossart et al., 1998; Frerking et al., 1998; Mulle et al., 1998; Bureau et al.,

\footnotetext{
Received July 17, 2000; revised Aug. 23, 2000; accepted Aug. 29, 2000.

This research was supported by an International Prize Fellowship from the Wellcome Trust (A.C.), a Young Investigator Award from the National Alliance for Schizophrenia and Depression (G.T.S.), the Schweizerische Nationalfond and the Deutsche Forschungsgemeinschaft (A.S.), and the National Institutes of Health and the McKnight Foundation (S.F.H.). We would like to acknowledge the technica efforts of Conny Maron and Lora O'Leary. We also would like to thank Drs. Robert Gereau, Jane Sullivan, and Charles F. Stevens for critical reading of this manuscript. A.C. and G.T.S. contributed equally to this work.

Correspondence should be addressed to Dr. Anis Contractor, Molecular Neurobiology Laboratory, The Salk Institute for Biological Studies, 10010 North Torrey Pines Road, La Jolla, CA 92037. E-mail: contractor@salk.edu.

Dr. Sailer's present address: Merck and Company, Inc., P.O. Box R80M-213, Rahway, NJ 07065.

Copyright (C) 2000 Society for Neuroscience $0270-6474 / 00 / 208269-10 \$ 15.00 / 0$
}

and GluR5 ${ }^{-1-}$ mice but had no effect on EPSCs in neurons from GluR6 $^{-1-}$ mice. These results therefore contrast with previous studies that supported a role for GluR5-containing receptors at mossy fiber and associational-commissural synapses (Vignes et al., 1998; Bortolotto et al., 1999). Surprisingly, at perforant path synapses kainate receptor activation enhanced transmission; this potentiation was abolished in both GluR5 and GluR6 knockout mice. Kainate receptors thus play multiple and complex roles to modulate excitatory synaptic transmission in the CA3 region of the hippocampus.

Key words: presynaptic kainate receptors; CA3 pyramidal neurons; kainate receptor knock-out mice; hippocampus; mossy fiber; excitatory synaptic transmission

1999). Hippocampal kainate receptors also have presynaptic modulatory effects on glutamate (Chittajallu et al., 1996; Kamiya and Ozawa, 1998; Vignes et al., 1998) and GABA release in the CA1 region (Clarke et al., 1997; Rodriguez-Moreno et al., 1997; but also see Frerking et al., 1999).

In the CA3 region of the hippocampus, activation of presynaptic kainate receptors has been shown to depress excitatory input at mossy fibers and associational-commissural synapses. Most recently, Kamiya and Ozawa (2000) showed that application of low concentrations of kainate depressed MF transmission, which likely occurred because of kainate receptor-mediated axonal depolarization. Pharmacological experiments with a putative selective agonist supported the interpretation that glutamate receptor 5 (GluR5) subunits critically comprised presynaptic mossy fiber and associational-commissural kainate receptors (Vignes et al., 1998; Bortolotto et al., 1999). This result is surprising, because expression of GluR5 mRNA is confined predominantly to hippocampal interneurons and is not detectable in the dentate gyrus granule neurons or CA3 pyramidal neurons (Bahn et al., 1994; Paternain et al., 2000). In mouse hippocampus, granule neurons express high levels of GluR6, GluR7, and KA-2 mRNA, whereas pyramidal neurons express GluR6, KA-1, and KA-2 mRNA (Bureau et al., 1999).

In this study, we have used gene-targeted mice lacking GluR5 or GluR6 kainate receptor subunits to determine the identity of the subunit comprising presynaptic CA3 kainate receptors. Additionally, we extended our analysis of CA3 excitatory transmission to perforant path synapses, where we found that kainate receptors enhance, rather than depress, excitatory transmission. These studies lead us to conclude that the GluR6 receptor subunit comprises presynaptic kainate receptors that inhibit MF and associationalcommissural (A-C) neurotransmission.

\section{MATERIALS AND METHODS}

Horizontal hippocampal slices $(250-350 \mu \mathrm{m})$ were made from postnatal day 14 (P14) to P27 mice with the following genotypes: wild type, GluR6 $^{-1-}$, GluR5 ${ }^{-1-}$, and GluR5 ${ }^{-1-} / \mathrm{GluR6}^{-/-}$. The genetic background of the wild-type and GluR5 $5^{-1-}$ mice was isogenic $129 \mathrm{SvEv}$, 
whereas GluR6 ${ }^{-1-}$ and double knock-out mice had a hybrid 129SvEv/ C57BL/6 background. Developmental compensation could be a concern in knock-out experiments; however we feel this is unlikely because levels of mRNA expression of other kainate receptor subunits are unchanged in GluR6 $^{-1-}$ (Mulle et al., 1998) or GluR5 ${ }^{-1-}$ (A. Sailer, unpublished observations) mice. Furthermore, functional replacement of whole-cell kainate receptor currents arising from either GluR5- or GluR6-containing receptors does not occur in CA3 pyramidal neurons (Mulle et al., 1998), cerebellar Purkinje neurons (Brickley et al., 1999), or dorsal root ganglion neurons (G. T. Swanson, unpublished observation). Each knock-out mouse used in the study was genotyped by Southern blot analysis of tail DNA. Animals were anesthetized with methoxyflurane and decapitated. The brain was removed under ice-cold artificial CSF (ACSF) containing 125 $\mathrm{mm} \mathrm{NaCl}, 2.4 \mathrm{~mm} \mathrm{KCl}, 1.2 \mathrm{~mm} \mathrm{NaH}_{2} \mathrm{PO}_{4}, 25 \mathrm{~mm} \mathrm{NaHCO}_{3}, 25 \mathrm{~mm}$ glucose, $1 \mathrm{mM} \mathrm{CaCl}_{2}$, and $4 \mathrm{mM} \mathrm{MgCl}$, equilibrated with $95 \% \mathrm{O}_{2}$ and $5 \% \mathrm{CO}_{2}$. In some experiments, the $\mathrm{Mg}^{2+}$ concentration was reduced to $2 \mathrm{mM}$, and 50 $\mu \mathrm{M}$ D,L-2-amino-5-phosphonopentanoic acid (D,L-APV; Research Biochemicals, Natick, MA) and $300 \mu \mathrm{M}$ kynurenate (Tocris Cookson) were included in the slice or incubation solution. Slices were made on ice with a DSK microslicer (Dosaka Instruments) and transferred to a holding chamber at room temperature for a minimum of $1 \mathrm{hr}$. Individual slices were transferred to a recording chamber and visualized under Nomarsk optics by the use of a Zeiss Axioskop FS or FS2 (Carl Zeiss). Slices were continuously perfused with ACSF containing $4 \mathrm{~mm} \mathrm{CaCl}_{2}$ and $4 \mathrm{~mm}$ $\mathrm{MgCl}_{2}$. Whole-cell patch-clamp recordings were made from visually identified pyramidal cells in the CA3 region of the hippocampus. All experiments were done at room temperature. Glass electrodes were pulled from borosilicate glass and had resistances of 4-5 $\mathrm{M} \Omega$ when filled with an internal solution containing $95 \mathrm{~mm} \mathrm{CsF}, 25 \mathrm{~mm} \mathrm{CsCl}, 10 \mathrm{~mm}$ Cs-HEPES, $10 \mathrm{~mm}$ Cs-EGTA, 2 mm NaCl, 2 mm Mg-ATP, 10 mM QX-314, 5 mm tetraethyammonium chloride, and $5 \mathrm{~mm} 4-\mathrm{AP}$, with $\mathrm{pH}$ adjusted to 7.3 with $\mathrm{CsOH}$.

For evoked synaptic responses, slices were bathed in ACSF with $40 \mu \mathrm{M}$ bicuculline and $50 \mu \mathrm{M}$ D-AP-5 (from Research Biochemicals). Synaptic currents were evoked by a monopolar glass electrode positioned either in the dentate gyrus or stratum lucidum for MF stimulation, in the stratum radiatum or stratum oriens in the CA3 subfield for A-C stimulation, or in the stratum lacunosum moleculare on the border of the subiculum and area CA1 for perforant path (PP) stimulation (Berzhanskaya et al., 1998). The glass electrode was filled with extracellular solution, and current pulse width and intensity were altered to give a stable EPSC. A 40 or $50 \mathrm{msec}$ paired-pulse stimulation protocol was used, and data collection and analysis were done with pClamp 6 or 7 software (Axon Instruments, Foster City, CA). We defined a "failure" as a current record in which no detectable EPSC was observed above the baseline noise level. The level of resolution in our experiments was $\sim 10 \mathrm{pA}$. In experiments using wild-type and GluR5 ${ }^{-1-}$ mice, in which perforant path inputs were being recorded, $2 \mu \mathrm{M}$ baclofen was included in the external solution in a subset of the recordings to reduce the excitability of CA3 pyramidal neurons (Xiang and Brown, 1998). Comparison with recordings in which baclofen was omitted demonstrated that this concentration did not impact the action of kainate on excitatory synaptic transmission. Also, in a subset of wild-type and GluR5 ${ }^{-1-}$ slices, a cut was made that bisected the slice from the edge of the stratum oriens in the proximal CA3 area to the tip of the suprapyramidal blade of the dentate gyrus [protocol according to Berzhanskaya et al. (1998)]. Test pulses were given at $0.1 \mathrm{~Hz}$ for $5 \mathrm{~min}$ during drug application and $10-20$ min for baseline recordings.

For miniature EPSC (mEPSC) recordings, $1 \mu \mathrm{M}$ tetrodotoxin (TTX), 40 $\mu \mathrm{M}$ bicuculline methiodide, and $50 \mu \mathrm{M}$ D-AP-5 (all from Research Biochemicals) were included in the external solution. Neurons were voltageclamped at -60 to $-80 \mathrm{mV}$ using an Axopatch 200B amplifier (Axon Instruments), and series resistance was compensated at $60-70 \%$. Access was monitored periodically throughout the experiment. All drugs were bath-applied under gravity. Drugs used were $3 \mu \mathrm{M}$ kainate and $1 \mu \mathrm{M}$ RS-2-amino-3-(3-hydroxy-5-butylisoxazol-4-yl) propanoic acid (Research Biochemicals). Data were collected on DAT tape (Biological) and subsequently filtered at $1-2 \mathrm{kHz}$ and acquired onto a computer using a Digidata $1200 \mathrm{~B}$ analog-to-digital interface and Axotape 2 software (Axon Instruments). Analysis of mEPSCs was performed by the use of the Mini Analysis Program (Synaptosoft, Leonia, NJ). All records were fitted manually by screening through and picking events from the digitized data. The whole data file was fitted to check for stability of the recordings. Two to 3 min stretches of data were used for mEPSC frequency analysis. Data are presented as the mean \pm SEM. Parameters were compared by the use of the Student's unpaired $t$ test or the Wilcoxon signed rank test.

\section{RESULTS}

Presynaptic kainate receptors inhibit mossy fiber $\rightarrow$ and associational-commissural $\rightarrow$ CA3 synaptic transmission

CA3 pyramidal neurons receive excitatory inputs from three major pathways that form synaptic contacts with different regions of the pyramidal cell dendritic arbor: MFs from the dentate gyrus; A-C, or collateral, inputs from other hippocampal CA3 pyramidal neurons; and PP connections from layer II of the entorhinal cortex (Steward, 1976; Amaral and Witter, 1989). Bath application of kainate receptor agonists depresses excitatory synaptic transmission at MF and A-C synapses; this effect was postulated to arise from receptors containing the GluR5 receptor subunit (Vignes et al., 1998; Bortolotto et al., 1999). We initially sought to test this hypothesis by performing similar experiments in gene-targeted mice that lack GluR5 and GluR6 subunit receptors. We recorded EPSCs in hippocampal slices from wild-type and kainate receptor mutant mice while stimulating the afferent pathways with a glass electrode appropriately placed to activate the input of interest (see Materials and Methods). To confirm that we were stimulating the appropriate fibers, we used a pharmacological criterion, i.e., inhibition by the group II metabotropic GluR (mGluR) agonist $(2 S, 3 S, 4 S)$-CCG/(2S, 1'S , 2' $S)$-2-(carboxycyclopropyl)glycine (LCCG-1), to distinguish MF or PP input from A-C pathways (Kamiya et al., 1996; Macek et al., 1996). Bicuculline (40 $\mu \mathrm{M})$ and D-APV $(50 \mu \mathrm{M})$ were included in the external solution to block $\mathrm{GABA}_{\mathrm{A}}$ and NMDA receptors, respectively. The divalent cation concentration was raised to $4 \mathrm{mM} \mathrm{Ca}^{2+}$ and $4 \mathrm{mM} \mathrm{Mg}^{2+}$ while recording EPSCs to suppress seizure activity of the slice preparation. In some recordings, particularly those from wild-type and GluR5 ${ }^{-/-}$mice, the $\mathrm{GABA}_{\mathrm{B}}$ agonist baclofen $(2 \mu \mathrm{M})$ was included in the bathing solution to reduce collateral activation when PP inputs were stimulated (Xiang and Brown, 1998).

The first synaptic input we examined was the $\mathrm{MF} \rightarrow \mathrm{CA} 3$ pathway. Mossy fiber transmission has been shown to be depressed by low concentrations of kainate in a dose-dependent manner (Kamiya and Ozawa, 2000). In agreement with this previous study, we found that bath application of kainate $(3 \mu \mathrm{M})$ reduced the MF EPSC amplitude by $-85.7 \pm 4.8 \%(n=9$ slices from 5 animals; $p<$ 0.05 ; Fig. $1 A, C)$. This inhibition of the synaptic response was comparable with that observed with the mGluR2 agonist L-CGG-1, which reduced the evoked mossy fiber response by $-80.4 \pm 7.4 \%(n=9$ slices from 6 animals; $p<0.05$; Fig. $1 A, C)$. As was observed with L-CCG-1, activation of mossy fiber kainate receptors enhanced the likelihood of synaptic failure, which we simply defined as a stimulation event in which an EPSC was not detected above the baseline noise; in our recordings, the failure rate increased from a basal level of 1 to $43 \%(n=9)$ in the presence of kainate. The paired-pulse ratio for our recordings from wildtype mice (measured with an interval of $40 \mathrm{msec}$ ) was $2.6 \pm 0.4$ $(n=9)$. During kainate application, the paired-pulse ratio significantly increased to $4.5 \pm 1.0(n=9)$, suggesting that the release probability at the mossy fiber synapse had decreased (Manabe et al., 1993). Kainate-mediated suppression of the MF EPSC was not caused by indirect mechanisms, such as activation of mGluRs or $\mathrm{GABA}_{\mathrm{B}}$ receptors, because EPSC recordings in the presence of the mGluR antagonist $(S)$ - $\alpha$-methyl-4-carboxyphenylglycine $[(S)$ MCPG; $500 \mu \mathrm{M}$ ] or the $\mathrm{GABA}_{\mathrm{B}}$ antagonists 2-hydroxysaclofen $(200 \mu \mathrm{M})$ or $(+)-(2 S)-5,5$-dimethyl-2-morpholineacetic acid (SCH $50911 ; 10 \mu \mathrm{M})$ were inhibited by kainate to the same degree seen in control recordings [inhibition in $(S)-\mathrm{MCPG},-69.8 \pm 8.9 \% ; n=4$ slices from 2 animals; inhibition in 2-hydroxysaclofen, $-98.9 \pm$ $1.1 \%$, and in SCH 50911, $-79.1 \pm 9.0 \%$; combined $n=6$ from 2 animals]. These results confirm that kainate receptors localized to the MF axons or terminals can dramatically impact the efficacy of granule cell $\rightarrow \mathrm{CA} 3$ excitatory transmission and are consistent with data from previous studies (Kamiya and Ozawa, 1998; Vignes et al., 1998).

To determine which receptor subunit(s) comprised the MF presynaptic receptors, we evoked EPSCs in hippocampal slices from kainate receptor knock-out mice. In neurons from mice in which the GluR6 gene had been disrupted (GluR6 ${ }^{-1-}$ genotype) (Mulle et al., 1998), application of kainate had no effect on synaptic currents (the mean current amplitude in the presence of kainate was $4.1 \pm 7.1 \%$ compared with control; $n=5$ from 3 animals; $p=$ 0.9 ; Fig. $1 B, C)$. No change in the percent of failures of transmission was observed during kainate application in GluR6 ${ }^{-/-}$neurons, whereas L-CCG-1 application increased failures by $38 \pm 19 \%(n=$ 5 slices from 3 animals). In contrast, kainate inhibited MF EPSCs in neurons from mice that lack the GluR5 subunit (GluR5 
A mossy fiber - wildtype

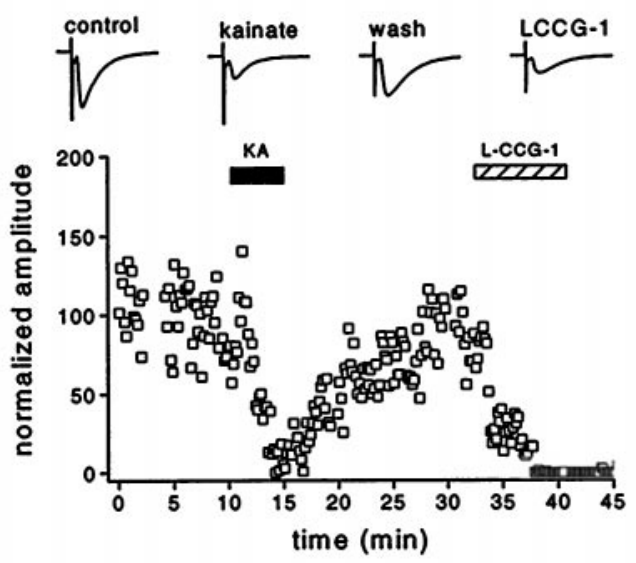

B mossy fiber - GluR6\%

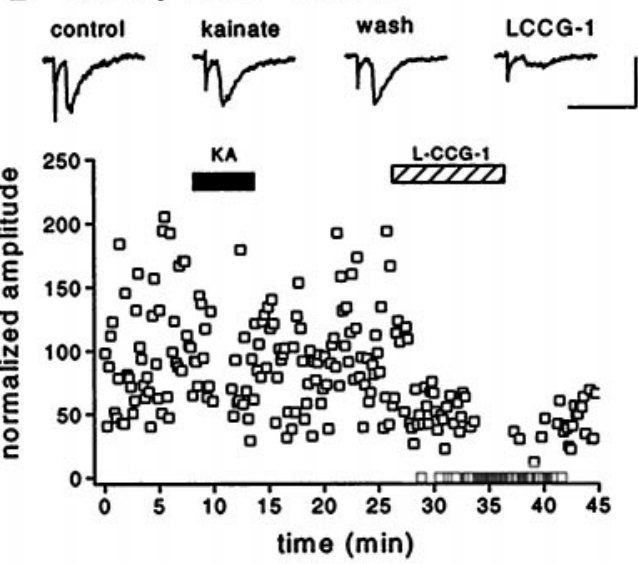

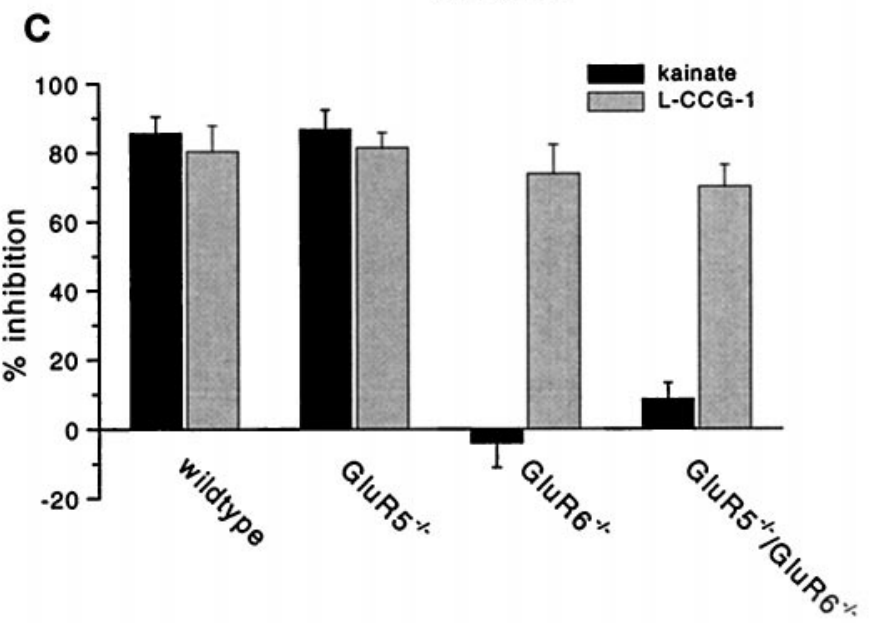

Figure 1. Mossy fiber $\rightarrow$ CA3 excitatory synaptic transmission is inhibited by activation of kainate receptors containing the GluR6 subunit. A, Middle, A representative experiment shows that the amplitudes of evoked AMPA receptor-mediated mossy fiber EPSCs were reduced by application of $3 \mu \mathrm{M}$ kainate to neurons in acute slices from wild-type mice. Top, Representative traces of EPSCs are shown. mGluR activation with $10 \mu \mathrm{M}$ L-CCG-1 suppressed transmission, which served to identify the input as a mossy fiber. EPSCs were evoked at $0.1 \mathrm{~Hz}$ frequency by monopolar stimulation in the stratum lucidum. Bottom, A diagram illustrates the slice preparation and recording configuration for mossy fiber stimulation. $B$, Kainate application to CA3 neurons from GluR6 ${ }^{-1-}$ mice did not inhibit excitatory transmission, whereas mGluR-mediated suppression was intact at these synapses. $C$, A summary of the effect of application of kainate on mossy fiber $\rightarrow$ CA3 recordings from the mice used in this study is shown. Mossy fiber transmission was suppressed by -85.7 $\pm 4.8 \%(n=9)$ in wild-type mice and $-86.8 \pm 5.6 \%(n=7)$ in GluR5 ${ }^{-1-}$ mice with $3 \mu \mathrm{M}$ kainate. No inhibition was seen in either GluR6 ${ }^{-1-}$ mice $(+4.1 \pm 7.1 \%$ change; $n=5)$ or GluR5 ${ }^{-1-} /$ GluR6 $^{-1-}$ mice $(-8.5 \pm 4.8 \%$ change; $n=4)$. Activation of mGluRs with L-CCG-1 suppressed mossy fiber transmission in each of the mice tested. Calibration: $A, x$-axis, $30 \mathrm{msec} ; y$-axis, $1500 \mathrm{pA} ; B, x$-axis, $30 \mathrm{msec} ; y$-axis, $66 \mathrm{pA}$. $D G$, Dentate gyrus.

genotype) (Mulle et al., 2000) to a degree similar to that in wild-type neurons $(-86.8 \pm 5.6 \%$ reduction of current amplitudes; $n=7$ slices from 3 animals; $p<0.05$; Fig. $1 C)$. MF synaptic currents were not altered by kainate application to slices from mice in which there was a null mutation in both the GluR5 and GluR6 genes (GluR5 ${ }^{-1-} /$ GluR6 $^{-1-}$ genotype), which were generated by interbreeding of the single-subunit knock-out strains (a change of $-8.5 \pm 4.8 \%$ was observed; $n=4$ from 4 animals). Presynaptic mGluR activation by L-CCG-1 suppressed MF EPSCs by $>70 \%$ in all the recordings from kainate receptor knock-out mice. Mossy fiber EPSC amplitudes in neurons from mutant mice were not significantly different from those in wild-type neurons $(p>0.1)$. These data suggest that activation of GluR6-containing receptors, but not GluR5-containing receptors, suppresses transmission at the $\mathrm{MF} \rightarrow \mathrm{CA} 3$ synapse in mice.

Activation of kainate receptors in CA3 pyramidal neurons produces a robust whole-cell current and reduces the input resistance, which could contribute to the apparent depression of the mossy fiber EPSC after application of kainate. Shunting of IPSCs was shown recently in part to underlie the action of kainate on inhibitory synaptic transmission in the CA1 region (Frerking et al., 1999). Application of $3 \mu \mathrm{M}$ kainate to slices from wild-type and GluR5 ${ }^{-1-}$ mice elicited whole-cell currents in CA3 pyramidal neurons that were of similar amplitude (wild type, $491 \pm 58 \mathrm{pA}$; $n=27$; GluR5 ${ }^{-1-}, 527 \pm 59 \mathrm{pA} ; n=23$ ), whereas little or no current was observed in neurons from GluR6 ${ }^{-1-}(11 \pm 5 \mathrm{pA} ; n=$ 30) or GluR5 ${ }^{-1-} /$ GluR6$^{-1-}(7 \pm 3 \mathrm{pA} ; n=20)$ mice. To test whether a reduction in input resistance accounted for the kainatemediated depression of mossy fiber EPSCs, we measured the time course and correlation of the input resistance and EPSC amplitude for each stimulus in recordings from five neurons from wild-type animals (Fig. 2). We first determined that the input resistance of CA3 pyramidal neurons decreases during kainate application, as indicated by the increased holding current during a $-10 \mathrm{mV}$ step from the command voltage of $-60 \mathrm{mV}$ when kainate was present in the bathing solution (Fig. $2 A$, top). Concurrently, the EPSC is profoundly depressed or eliminated (Fig. $2 A$, bottom). However, the input resistance increases to the original prekainate value when the drug was removed from the bath (Fig. $2 B$ ). In contrast, the mossy fiber EPSC remains depressed for a considerable period after drug application (Fig. 2B). Although the input resistance recovered to normal levels within $\sim 7 \mathrm{~min}$ after washout of kainate, EPSCs were still depressed by $\sim 40 \%$ after $15 \mathrm{~min}$. Additionally, normalized EPSC amplitudes do not correlate with the input resistance; depression of the EPSC by nearly $70 \%$ can occur without significant reductions in the input resistance (Fig. $2 C$ ). It should 
A

Figure 2. Depression of the mossy fiber EPSC is not caused by a reduction in the input resistance of the pyramidal neuron. $A$, Top, The increased holding current during a $-10 \mathrm{mV}$ step applied before the evoked EPSC demonstrates that the input resistance of the cell is reduced after application of kainate. Bottom, During kainate application, mossy fiber EPSCs failed or were greatly reduced in amplitude. $B$, The mean input resistance and normalized current plotted against the time of the recording show that both are reduced during kainate application. However, input resistance recovers fully by $\sim 7 \mathrm{~min}$ after kainate application, while the EPSC amplitude is still significantly depressed. Input resistances and EPSC amplitudes were normalized to the respective means of the control periods before application of kainate. $C$, The mean input resistance is not correlated with the mean normalized EPSC (data from 5 neurons). Calibration: $A$, top, $x$-axis, $15.5 \mathrm{msec}$; $y$-axis, $1.2 \mathrm{nA}$; inset, $x$-axis, $14 \mathrm{msec} ; y$-axis, $0.3 \mathrm{nA}$; bottom; $x$-axis, 10 msec; $y$-axis, $300 \mathrm{pA}$.
B
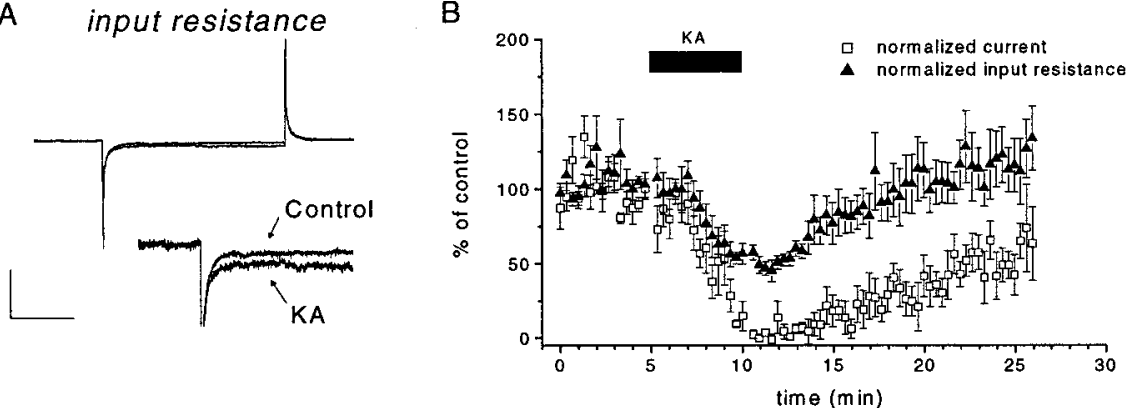

C

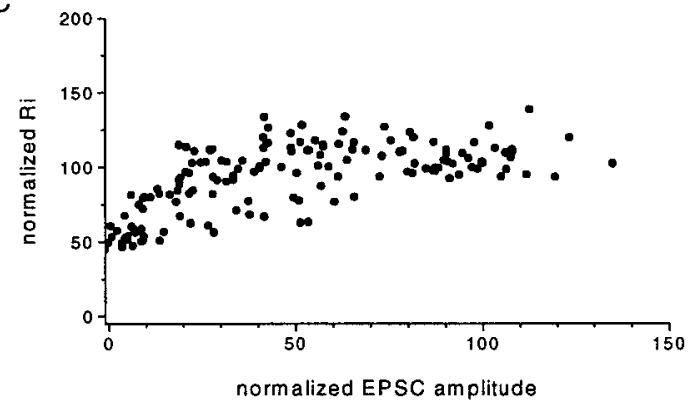

be noted that we cannot exclude the possibility that, in the presence of the whole-cell current, when the input resistance is reduced, shunting may contribute to the apparent depression of EPSC at more distal synapses. However, this is unlikely to contribute significantly to the long-lasting kainate-mediated depression of mossy synapses, because of the proximity of these synapses to the cell soma.

We next explored kainate receptor modulation of associationalcommissural inputs to CA3 neurons, which are formed from axon collaterals of other pyramidal neurons in the CA3 region (Fig. $3 A$, bottom). ATPA, a putative GluR5-selective agonist, has been reported to reduce A-C EPSC amplitude (Bortolotto et al., 1999). Application of $3 \mu \mathrm{M}$ kainate to slices from wild-type mice suppressed transmission to a degree similar to that seen at the $\mathrm{MF} \rightarrow \mathrm{CA} 3$ synapse $(-90.0 \pm 4.0 \% ; n=12$ slices from 7 animals; $p<0.01$; Fig. $3 A, C)$. In addition, the number of failures of transmission increased by $77 \pm 8 \%$. The group II mGluR agonist L-CCG-1 did not depress synaptic currents (the percent change of EPSC in L-CCG-1 was $+4.8 \pm 13.3 \% ; n=8$ slices from 7 animals), verifying that the currents were not significantly contaminated by either MF or PP inputs. Application of kainate to neurons in slices from GluR6 ${ }^{-1-}$ mice did not reduce A-C synaptic currents (the relative amplitude of EPSCs in kainate was $-8.7 \pm 2.8 \% ; n=8$ slices from 5 animals; Fig. 3B,C). Similar to the effect seen in wild-type mice, A-C EPSCs in neurons from the GluR5 ${ }^{-1-}$ mice were suppressed by $-80.5 \pm 11.9 \%$ after application of kainate $(n=5$ slices from 4 animals; $p<0.05$; Fig. $3 C)$. Finally, there was no kainate-mediated inhibition of A-C EPSCs in the GluR5 ${ }^{-1-}$ / GluR6 $^{-1-}$ mice $(-2.8 \pm 4.8 \% ; n=3$ slices from 1 animal; Fig. $3 C$ ). A-C inputs in neurons from the knock-out mice were relatively insensitive to L-CCG-1 (inhibition of EPSCs by L-CCG-1 in all the genotypes tested was $<14 \%$ ). These data suggest that in CA3 pyramidal neurons kainate receptors containing the GluR6 subunit are located both postsynaptically at MF synapses (Castillo et al., 1997; Vignes and Collingridge, 1997; Mulle et al., 1998) and presynaptically at collateral synapses on other CA3 pyramidal neurons, where they can inhibit A-C excitatory transmission.

\section{Perforant path transmission to CA3 neurons is potentiated by kainate receptor activation}

In our final set of experiments we examined EPSCs arising from stimulation of the PP, which projects to the CA3 from layer II of the entorhinal cortex. The action of kainate receptors on transmission at PP synapses has not been reported previously. The stimulating electrode was placed in the stratum lacunosum moleculare, on the border of the subiculum and area CA1 (Fig. 4E, left), and in some slices a cut was made between the DG and CA3 to reduce contamination of the MF input (Berzhanskaya et al., 1998). We also used $2 \mu \mathrm{M}$ baclofen, a GABA $\mathrm{B}_{\mathrm{B}}$ agonist, to hyperpolarize CA3 neurons and thereby eliminate collateral activation of A-C inputs subsequent to perforant path EPSCs (Xiang and Brown, 1998). PP inputs were identified by the rapid rise times, relatively long latencies, and suppression of the EPSC by the mGluR agonist L-CCG-1.

In contrast to the effect seen at MF and A-C synaptic inputs, an enhanced PP synaptic response was observed after application of 3 $\mu \mathrm{M}$ kainate to wild-type mice (Fig. $4 A, E$ ). Kainate application produced a reversible increase in EPSC amplitude $(+170 \pm 74 \%$; $n=7$ slices from 5 animals; $p<0.05)$. The paired-pulse ratio was similar for EPSCs before and during kainate application (control, $2.1 \pm 0.2$, vs kainate, $2.1 \pm 0.3$ ). Synaptic failures decreased by fourfold, from $37 \pm 13$ to $9 \pm 6 \%$.

In neurons from GluR5 $5^{-1-}$ mice, kainate application caused either a decrease $(-38.9 \pm 3.9 \% ; n=5$ slices from 4 animals $)$ or an increase $(+44.9$ and $+113.3 \% ; n=2$ slices from 2 animals $)$ in the amplitude of the synaptic currents (total mean change of all recordings is $-5.2 \pm 23.2 \%$; Fig. $4 C, E$ ). There was no difference in evoked amplitude, synaptic failure rate, or kainate-mediated whole-cell current amplitude between the PP inputs that were inhibited compared with those that potentiated. However, the two synaptic inputs that potentiated showed marked decreases in the paired-pulse facilitation (reduction of -52 and $-43 \%$ ) and synaptic failure rate (reduction of -40 and $-60 \%$ ) in the presence of kainate. In contrast, paired-pulse facilitation was unaffected by drug application in the subpopulation of synaptic currents that were reduced by kainate (control paired-pulse ratio of $2.3 \pm 0.3$ vs the kainate paired-pulse ratio of $2.2 \pm 0.4$ ). In addition, synaptic failures increased slightly in this subset of responses (control, $22 \pm$ $15 \%$, vs kainate, $32 \pm 15 \% ; p>0.05$ ).

In neurons from GluR6 ${ }^{-/-}$mice, kainate application consistently caused a significant reduction in the amplitude of PP synaptic currents $(-38.1 \pm 8.1 \% ; n=7$ slices from 5 animals; $p<0.05$; Fig. $4 B, E)$. No PP EPSCs in neurons from GluR6 $6^{-1-}$ mice showed an increase in amplitude similar to that observed in the wild-type neurons or in the two potentiated neurons from GluR5 $5^{-1-}$ mice. Furthermore, paired-pulse facilitation ratios were similar in GluR6 $^{-1-}$ neurons before $(2.0 \pm 0.2)$ and during $(2.1 \pm 0.2)$ application of kainate. Synaptic failures increased from $3 \pm 3$ to $22 \pm 9 \%$ when kainate was applied. 


\section{A associational-commissural-wildtype}
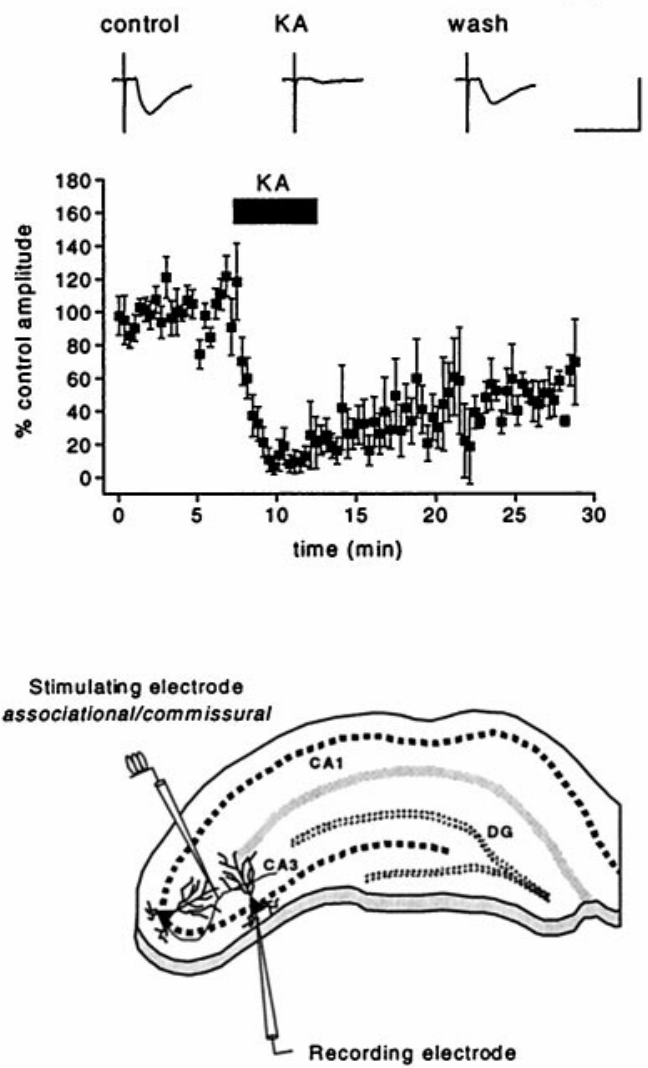

B associational-commissural-GluR $6^{\%}$
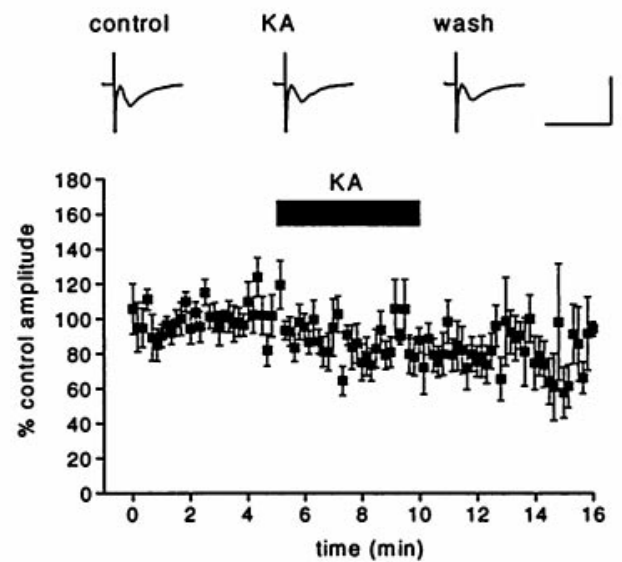

C

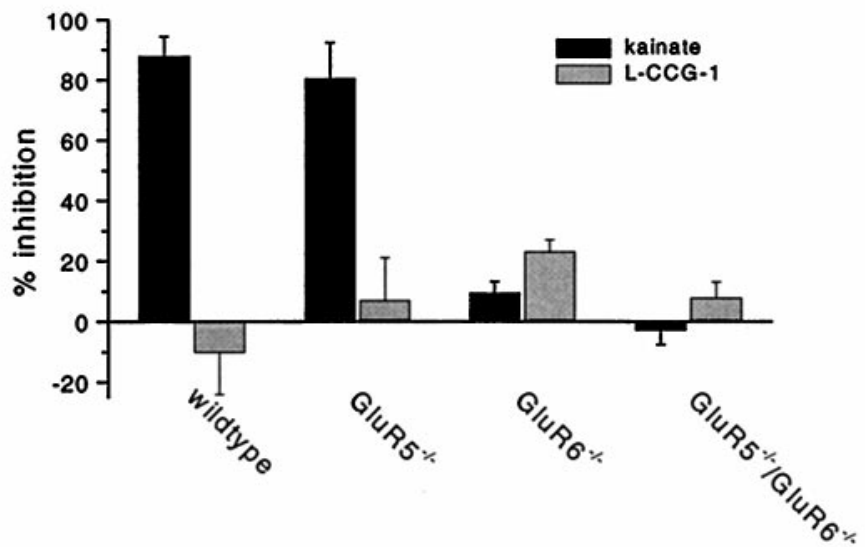

Figure 3. Associational-commissural synaptic transmission is suppressed by activation of kainate receptors containing the GluR6 subunit. A, Middle, Associational-commissural EPSC amplitudes from wild-type CA3 neurons were suppressed by kainate application $(n=9)$. Amplitudes of the EPSCs were normalized to the mean EPSC amplitude during the control period before application of kainate. Top, Representative EPSCs from one wild-type recording are shown. EPSCs were evoked at $0.1 \mathrm{~Hz}$ frequency by stimulation in the stratum radiatum. Bottom, A diagram illustrates the slice preparation and recording configuration for associational-commissural stimulation. The stimulating electrode is shown in the stratum radiatum; EPSCs were also evoked by stimulation in the stratum oriens. B, Bottom, Associational-commissural synaptic transmission is not inhibited by $3 \mu \mathrm{M}$ kainate in CA3 pyramidal neurons from GluR6 ${ }^{-1-}$ mice $(n=7)$. Amplitudes of the EPSCs were normalized to the mean EPSC amplitude during the control period before application of kainate. Top, Representative EPSCs from one recording are shown. $C$, A summary of the effect of application of kainate on associationalcommissural $\rightarrow$ CA3 recordings from the mice used in this study is shown. Collateral transmission was suppressed by $-90.0 \pm 4.0 \%(n=12)$ in wild-type mice and $-80.5 \pm 11.9 \%(n=5)$ in GluR5 ${ }^{-1-}$ mice with $3 \mu \mathrm{M}$ kainate. No inhibition was seen in either GluR6 ${ }^{-1-}$ mice $(-8.7 \pm 2.8 \%$ change; $n=8)$ or GluR5 $^{-1-} /$ GluR6 $^{-1-}$ mice $(-2.8 \pm 4.8 \%$ change; $n=3)$. mGluR activation with L-CCG-1 did not suppress associational-commissural transmission in these recordings. Calibration: $A, x$-axis, 30 msec; $y$-axis; $200 \mathrm{pA} ; B, x$-axis, 30 msec; $y$-axis, $75 \mathrm{pA}$.

Finally, we tested the effect of kainate on PP inputs in GluR5 $5^{-1-}$ GluR6 $^{-1-}$ mutant mice. These knock-out mice showed no significant alteration in EPSCs when kainate was applied (amplitude change of $1.2 \pm 6.6 \% ; n=4$ slices from 2 animals; Fig. $4 D, E$ ). Similarly, there were no differences in either the paired-pulse ratio $(2.1 \pm 0.1$ in control and $1.8 \pm 0.3$ in kainate $)$ or synaptic failure rate ( $12 \pm 10 \%$ during control and $16 \pm 16 \%$ in kainate) in the GluR5 ${ }^{-/}$ $-/$ GluR6 ${ }^{-/-}$mutant mice. These results suggest that both GluR5 and GluR6 receptor subunits contribute to kainate receptormediated potentiation of PP synaptic transmission at synapses on CA3 neurons.

\section{Kainate application increases mEPSC frequency in CA3 neurons}

Because of the striking effect of kainate receptor activation on evoked EPSCs and the changes in the paired-pulse ratio in MF EPSCs, we examined whether kainate application altered mEPSCs frequencies under our recording conditions. A previous study reported that mEPSC frequencies were not altered when kainate was applied to CA3 pyramidal neurons (Castillo et al., 1997). mEPSCs were recorded in the presence of $1 \mu \mathrm{M}$ TTX, $50 \mu \mathrm{M}$ D-APV, and 40 $\mu \mathrm{M}$ bicuculline. Bath application of $3 \mu \mathrm{M}$ kainate significantly increased mEPSC frequency by 2.2-fold, from a basal rate of $0.65 \pm$ 0.14 to $1.41 \pm 0.26 \mathrm{~Hz}$ ( $n=16$ slices from 9 animals; $p<0.05$; Fig. $5)$. We observed increases in frequency $>1$.2-fold over basal levels in 11 of the 16 neurons recorded. The mEPSC frequency in 2 of the 16 neurons decreased after application of kainate, whereas rates were unchanged in the remaining 3 recordings. These data suggest that presynaptic kainate receptors can modulate action potentialindependent glutamate release at a subset of excitatory synapses onto CA3 pyramidal neurons.

To test which kainate receptors might be mediating this effect, we again made recordings from the kainate receptor knock-out mice. We first measured mEPSC frequencies in CA3 neurons from GluR5 ${ }^{-1-}$ mice. In contrast to neurons in wild-type mice, in CA3 neurons from GluR5 ${ }^{-1-}$ mice the mEPSC frequency did not change after application of kainate (control, $0.61 \pm 0.07 \mathrm{~Hz}$; kainate, $0.51 \pm 0.13 \mathrm{~Hz} ; n=10$ slices from 6 animals; Fig. $6 A$ ). mEPSC frequencies in CA3 neurons from GluR6 ${ }^{-1-}$ mice increased by 1.9 ( \pm 0.4$)$-fold, from $0.55 \pm 0.09$ to $1.15 \pm 0.37 \mathrm{~Hz}(n=$ 12 slices from 5 animals; $p<0.05)$, with no change in mEPSC amplitude (Fig. 6B). The mean fold increase in mEPSC frequencies after application of kainate to GluR6 ${ }^{-1-}$ neurons was not 


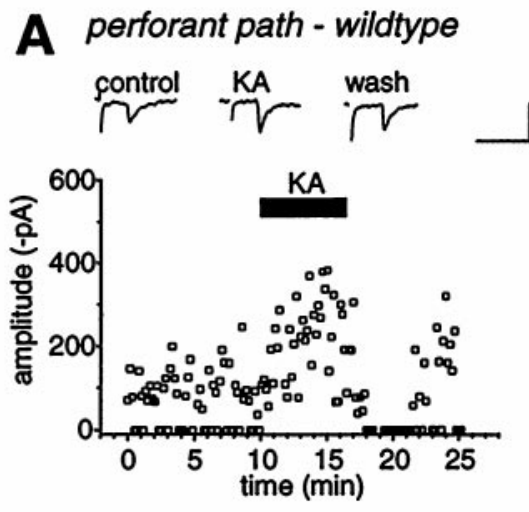

Figure 4. Perforant path synaptic transmission is augmented by activation of kainate receptors. $A$, Bottom, A representative recording from a wild-type CA3 neuron demonstrating that amplitudes of evoked perforant path EPSCs were increased and failures were decreased reversibly during kainate application. Top, Representative EPSCs. EPSCs were evoked at $0.1 \mathrm{~Hz}$ frequency by monopolar stimulation in the stratum lacunosum moleculare. $B, A$ representative recording from a GluR6 ${ }^{-1-}$ CA3 neuron demonstrating that amplitudes of evoked perforant path EPSCs were decreased during kainate application. $C$, A recording from a GluR5 ${ }^{--}$CA3 neuron that showed a reduction in EPSC amplitude during kainate application. Perforant path transmission in GluR5 $^{-1-}$ neurons showed variable responses to $3 \mu \mathrm{M}$ kainate; four of six synaptic responses were reduced, whereas EPSC amplitudes increased in the remaining two of six recordings. $D$, A representative recording from a GluR5 ${ }^{-/-} / \mathrm{GluR}^{-1-} \mathrm{CA} 3$ neuron demonstrating that amplitudes of evoked perforant path EPSCs were unchanged during kainate application. E, Left, A diagram illustrating the slice preparation and recording configuration for perforant path stimulation. Right, Summary of the effect of application of kainate on perforant path $\rightarrow$ CA3 EPSCs. PP transmission was enhanced by $+170 \pm 74 \%$ in wild-type mice. GluR5 ${ }^{-1-}$ neurons had variable responses to kainate-in four of six recordings kainate reduced EPSC amplitudes by $-38.9 \pm 3.9 \%$, but in two neurons the amplitudes were increased by +44.9 and $+113.3 \%$. The mean for all six recordings, $-5.2 \pm 23.2 \%$, is shown in the histogram. The mean change in GluR6 $^{-1-}$ EPSC amplitudes was $-38.1 \pm$ $8.1 \%$. Finally, GluR5 ${ }^{-1-} / \mathrm{GluR6}^{-1-}$ mice showed little change in amplitude during kainate application $(+1.2 \pm 6.6 \%)$. mGluRs activation with L-CCG-1 did not reduce associational-commissural transmission in these recordings. Calibration: $A$, $x$-axis, 32.5 msec; $y$-axis, $300 \mathrm{pA} ; B$, $x$-axis, $32.5 \mathrm{msec} ; y$-axis, $150 \mathrm{pA} ; C, x$-axis, 32.5 msec; $y$-axis, 150 pA; $D, x$-axis, 32.5 msec; $y$-axis, $300 \mathrm{pA}$.

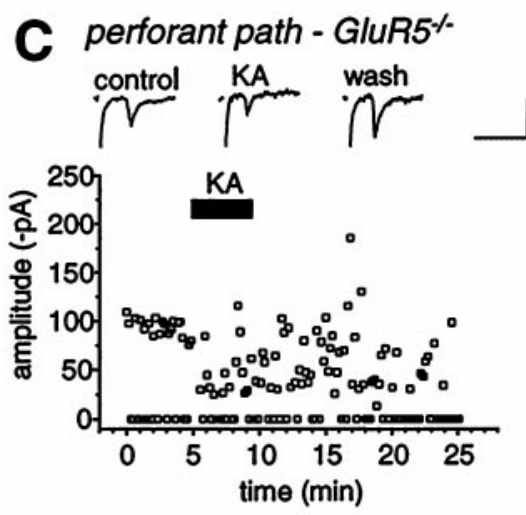

E

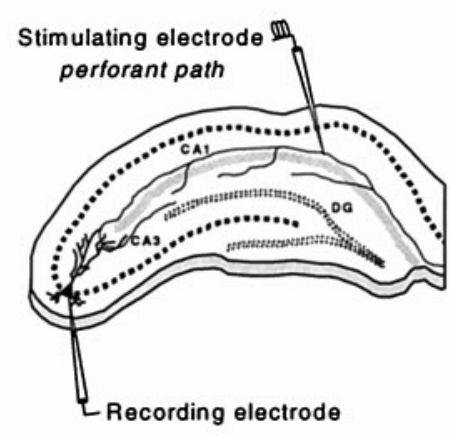

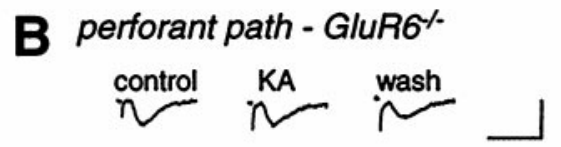

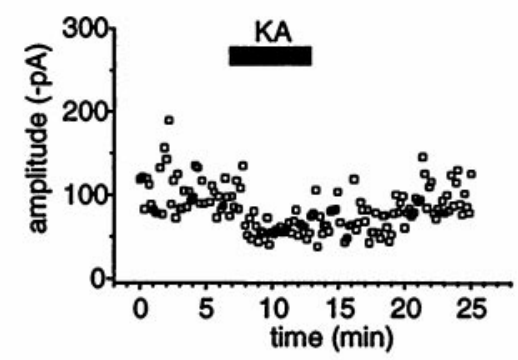

D perforant path - GluR5\%/GluR6\%
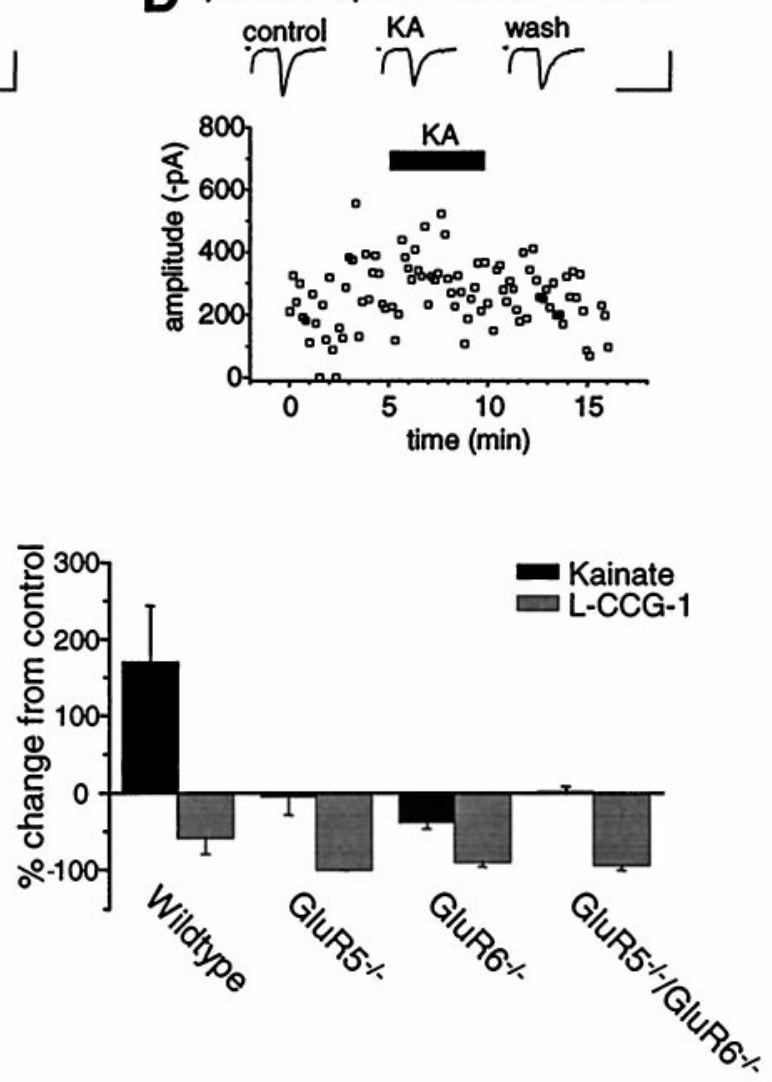

significantly different from that in wild-type neurons $(p>0.1)$. Finally, in neurons from GluR5 ${ }^{-/-} / \mathrm{GluR}^{-/-}$double knock-out mice, kainate did not cause any significant change in mEPSC frequency (control, $0.79 \pm 0.16 \mathrm{~Hz}$, vs kainate, $0.69 \pm 0.13 \mathrm{~Hz} ; p=$ $0.1 ; n=12$ slices from 5 animals; Fig. $6 C$ ). Therefore, kainate had little effect on mEPSC frequency in GluR5 $5^{-1-} / \mathrm{GluR}^{-1-}$ neurons, similar to the GluR5 ${ }^{-1-}$ recordings, and both genotypes differed significantly from the increase observed in wild-type neurons $(p<$ $0.05)$. Taken together, our mEPSC recordings from the different genotypes provide evidence that kainate receptors mediate enhancement of action potential-independent glutamate release onto CA3 pyramidal neurons via GluR5-containing receptors. These data suggest that the GluR5 subunit is located presynaptically at one or more types of excitatory inputs to CA3 pyramidal neurons and that GluR6 subunit-containing kainate receptors are unlikely to underlie the kainate-mediated increase in mEPSC frequency.

To determine whether the GluR5 receptor-mediated potentiation of mEPSC frequency involved activation of voltage-gated $\mathrm{Ca}^{2+}$ channels, we repeated the experiments in the presence of the nonselective $\mathrm{Ca}^{2+}$ channel blocker cadmium $\left(\mathrm{Cd}^{2+}\right)$. Bath appli- cation of cadmium-containing external solution alone did not alter the mEPSC frequency significantly $(p>0.1$ for all genotypes, paired Student's $t$ test). Surprisingly, kainate application in the presence of $200 \mu \mathrm{M} \mathrm{CdCl}{ }_{2}$ decreased mEPSC frequency in wildtype mice from $1.15 \pm 0.47$ to $0.54 \pm 0.16 \mathrm{~Hz}$, a reduction of 0.53 -fold $(n=5$ slices from 4 animals; $p<0.05$, Wilcoxon signed rank test; Fig. $6 E$ ). This concentration of $\mathrm{Cd}^{2+}$ does not reduce peak or steady-state kainate receptor currents in cultured hippocampal or dorsal root ganglion neurons or recombinant GluR5 receptors (G. T. Swanson and A. Ghetti, unpublished observations). These data suggest that the GluR5-dependent increase in mEPSC frequency involves activation of presynaptic $\mathrm{Ca}^{2+}$ channels.

To determine the subunits comprising receptors underlying the decrease in mEPSC frequency in the presence of cadmium, we recorded mEPSCs in the presence of cadmium in the mutant mice. The kainate-mediated decrease in mEPSC frequency in the presence of $\mathrm{Cd}^{2+}$ was also observed in the GluR5 $5^{-1-}$ mice $[0.70( \pm$ 0.09 )-fold change; $n=5 ; p<0.05]$, whereas there was no change in mEPSC frequency in the GluR6 ${ }^{-/-}$mice $[0.92( \pm 0.15)$-fold 
A

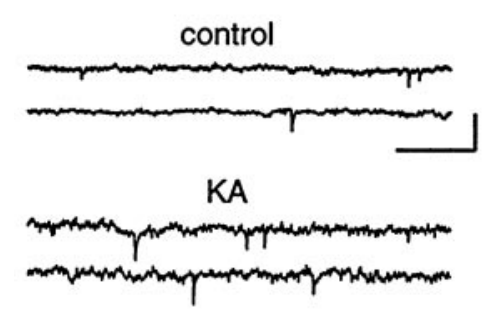

C

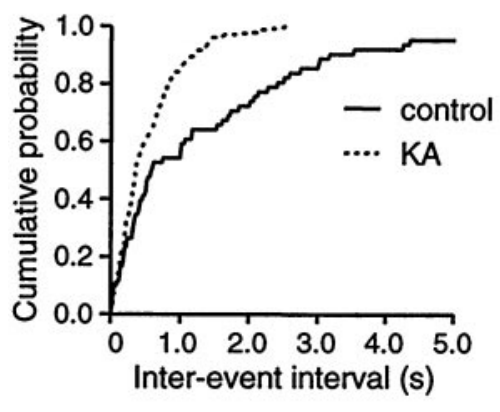

B

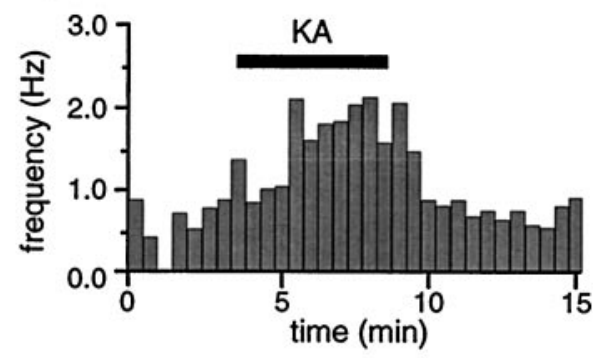

D

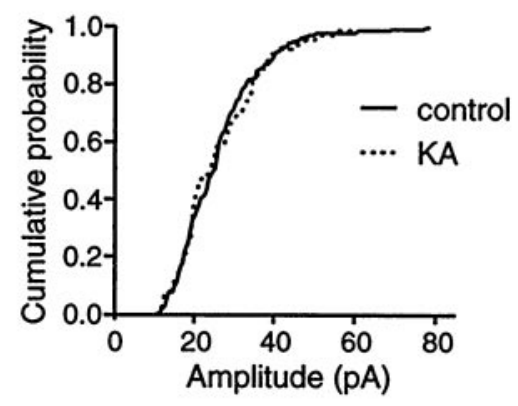

Figure 5. mEPSC frequency is increased by application of kainate to $\mathrm{CA} 3$ pyramidal neurons from wild-type mice. A, Sample traces of mEPSC recordings from a CA3 pyramidal neuron in a hippocampal slice preparation from a wild-type mouse. Kainate was bath-applied at a concentration of $3 \mu \mathrm{M}$. The baseline noise is higher during kainate application because of the kainate receptor-mediated whole-cell current. $B$, Histogram from the same cell shown in $A$ showing the mEPSC frequency in $30 \mathrm{sec}$ bins. Kainate caused the mEPSC frequency to increase by $\sim 1.7$-fold in this cell. The gap in the third bin resulted from checking the series resistance of the recording. The cell was whole-cell patch clamped at $-60 \mathrm{mV}$ for the duration of the recording. $C, D$, Cumulative probability graphs of mEPSC interevent intervals $(C)$ and amplitudes $(D)$. Interevent intervals were significantly decreased in the presence of kainate, whereas amplitudes were unchanged. Calibration: $A, x$-axis, $400 \mathrm{msec} ; y$-axis, $40 \mathrm{pA}$. change; $n=6 ; p>0.05$; Fig. $6 E$ ]. As expected, there was also no decrease in the mEPSC frequency in GluR5 $5^{-1-} / \mathrm{GluR}^{-/}$double knock-out mice in the presence of $\mathrm{Cd}^{2+}$ after application of kainate $[1.12( \pm 0.13)$-fold change; $n=7 ; p>0.05$; Fig. $6 E]$. These results suggest that the depression of $\mathrm{mEPSC}$ frequency uncovered by blockade of voltage-gated calcium channels was mediated by GluR6-containing receptors. In total, these results suggest that presynaptic kainate receptors can have heterogeneous and complex actions on mEPSC frequencies.

Analysis of the basic characteristics of mEPSCs in CA3 neurons from the kainate receptor knock-out mice revealed that there were no significant differences in any of the genotypes compared with wild-type neurons. Basal frequencies of mEPSCs were comparable between genotypes (mean control mEPSC frequencies, wild type, $0.65 \pm 0.14 \mathrm{~Hz}$; GluR5 ${ }^{-/-}, 0.61 \pm 0.07 \mathrm{~Hz}$; GluR6 ${ }^{-/-}, 0.55 \pm 0.09$ $\mathrm{Hz}$; GluR5 ${ }^{-/-} /$GluR6 $^{-/-}, 0.79 \pm 0.16 \mathrm{~Hz}$ ). Similarly, mean amplitudes were not significantly different (wild type, $25.0 \pm 1.6 \mathrm{pA}$; GluR5 $^{-/-}, 29.5 \pm 3.1 \mathrm{pA}$; GluR6 ${ }^{-/-}, 21.1 \pm 1.7 \mathrm{pA}$; GluR5 ${ }^{-/-}$ GluR6 $\left.^{-1-}, 24.1 \pm 2.4 \mathrm{pA}\right)$, nor were they altered in the presence of kainate (wild type, $26.6 \pm 1.9 \mathrm{pA}$; GluR5 $5^{-/-}, 34.5 \pm 4.3 \mathrm{pA}$; GluR6 $^{-1-}, 22.0 \pm 2.4 \mathrm{pA}$; GluR5 ${ }^{-/-} / \mathrm{GluR6}^{-/-}, 23.0 \pm 2.3 \mathrm{pA}$ ). This would suggest that there is little or no tonic activation of the presynaptic kainate receptors that modulate mEPSC frequencies in the slice preparation.

\section{DISCUSSION}

We have shown that kainate receptors comprised of GluR5 and GluR6 subunits play a role in modulating excitatory synaptic transmission to hippocampal CA3 pyramidal neurons. Activation of kainate receptors can either decrease synaptic strength, at mossy fibers and associational-commissural inputs, or increase synaptic strength at perforant path inputs. In contrast to previous reports, which relied on pharmacological characterization of kainate receptors, we used kainate receptor knock-out mice to identify receptor subunits that comprise presynaptic kainate receptors. In this way we determined that the GluR6 subunit is critically involved in inhibiting transmission at both the MF and A-C pathways, whereas both GluR5 and GluR6 subunits are involved in increasing transmission at the perforant path. These results support the hypothesis that kainate receptors act as one of the major signaling systems for modulating excitatory transmission in the CA3 region of the hippocampus.

\section{Kainate receptor-mediated depression of synaptic transmission}

Several groups have reported that kainate receptors can act presynaptically to reduce the strength of hippocampal excitatory transmission at mossy fiber and collateral synapses (Vignes et al., 1998; Bortolotto et al., 1999; Kamiya and Ozawa, 2000). We compared the effect of kainate on CA3 synaptic transmission in wild-type and kainate receptor knock-out mice to determine which receptor subunits are involved in this action. Kainate profoundly reduced EPSCs evoked by stimulation of MF and A-C collaterals in neurons from wild-type and GluR5 $5^{-1-}$ mice; in contrast, kainate had no significant effect on EPSC amplitudes recorded from neurons from GluR6 ${ }^{-1-}$ mice. The increase in paired-pulse facilitation at MF synapses that we observed during kainate receptor activation is consistent with a reduction in release probability (Manabe et al., 1993). This action of kainate suggests that in addition to axonal depolarization reported by Kamiya and Ozawa (2000), kainate receptors may also mediate their effect by a direct reduction in release probability at $\mathrm{MF} \rightarrow \mathrm{CA} 3$ synapses. Definitive localization of the receptor protein, which would facilitate interpretation of functional data, awaits the development of specific and sensitive antibodies to kainate receptor subunits.

Our data from gene-targeted mice contrast with pharmacological studies that explored the contribution of GluR5-containing kainate receptors to presynaptic actions on MF transmission. Vignes et al. (1998) found that ATPA, a putative GluR5-selective agonist, depressed transmission at mossy fiber synapses. Because of the apparent divergence between our data and that of Vignes et al. (1998), we also looked for ATPA-mediated depression of MF EPSCs; however, in our experiments ATPA $(1 \mu \mathrm{M})$ had no significant effect on amplitudes of MF EPSCs in wild-type mice (data not shown). This absence of ATPA-mediated depression therefore precludes a direct test of the selectivity of the compound in GluR5 ${ }^{-1-}$ mice. We are unsure why this discrepancy exists between our current results and those from Vignes and coworkers. It is possible that the pharmacological action of putative GluR5selective compounds may differ between native and recombinant kainate receptors. Also, one potential explanation that may reconcile the pharmacological and genetic observations is formation of heteromeric neuronal kainate receptors composed of both GluR5 and GluR6 subunits (and potentially KA-1 and KA-2 subunits), 

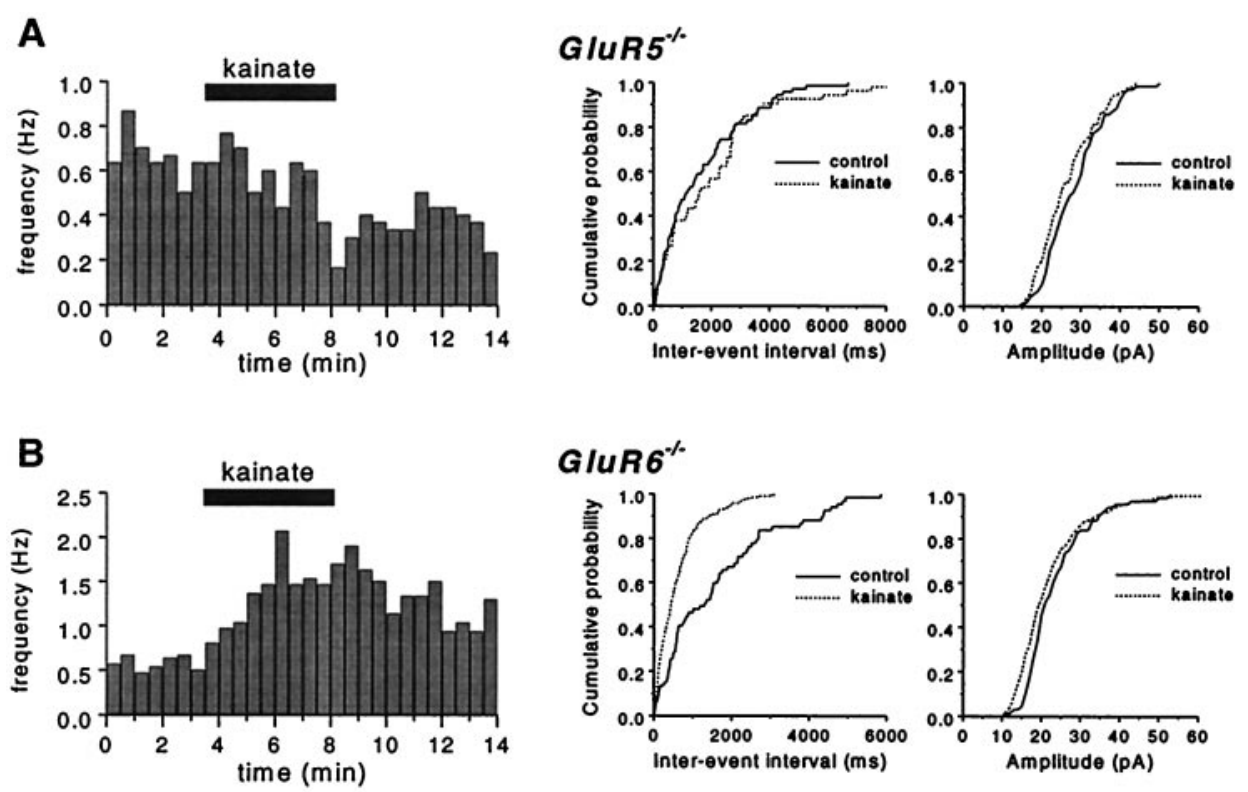

Figure 6. GluR5 subunit-containing kainate receptors underlie the kainate-mediated increase in mEPSC frequency. A, Left, A mEPSC frequency histogram for a CA3 neuron from a GluR5 $5^{-1-}$ mouse shows a small decrease in frequency during kainate application. Middle, Right, No significant difference in the interevent interval (middle) or amplitude (right) cumulative distributions was detected. $B$, An mEPSC frequency histogram for a CA3 neuron from a GluR6 ${ }^{-1-}$ mouse shows an increase in frequency during kainate application similar to that observed in wild-type neurons. The cumulative probability histograms show that the interevent intervals are significantly briefer in the presence of kainate but that amplitudes are unchanged. $C$, The mEPSC frequency for a CA3 neuron from a GluR5 $^{-1-} /$ GluR6 $^{-1-}$ mouse does not change after application of kainate. No significant differences in the interevent interval or amplitude cumulative distributions were observed. $D, \mathrm{~A}$ summary of all experiments for kainatemediated changes in mEPSC frequency for recordings from wild-type and kainate receptor subunit knock-out mice is shown. mEPSCs from wild-type and GluR6 ${ }^{-1-}$ neurons increased after application of kainate. This increase in frequency is absent in GluR5 knockout mice, and instead a small decrease was observed. mEPSC frequencies in recordings from GluR5 ${ }^{-1-} /$ GluR6 $^{-1-}$ double knock-out mice show no change in mEPSC frequency in the presence of kainate. E, A summary of kainate-mediated changes in mEPSC frequency in wild-type and knock-out mice recorded in the presence of the nonselective $\mathrm{Ca}^{2+}$ channel blocker $\mathrm{Cd}^{2+}$ is shown. The mEPSC was depressed in wild-type and GluR5 ${ }^{-1-}$ mice, whereas no change in frequency was observed in GluR6 ${ }^{-1-}$ mice or the double knock-outs.

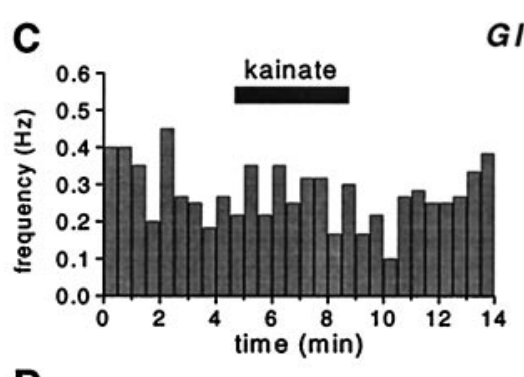

GIUR5 $\%$ GIUR6 $\%$
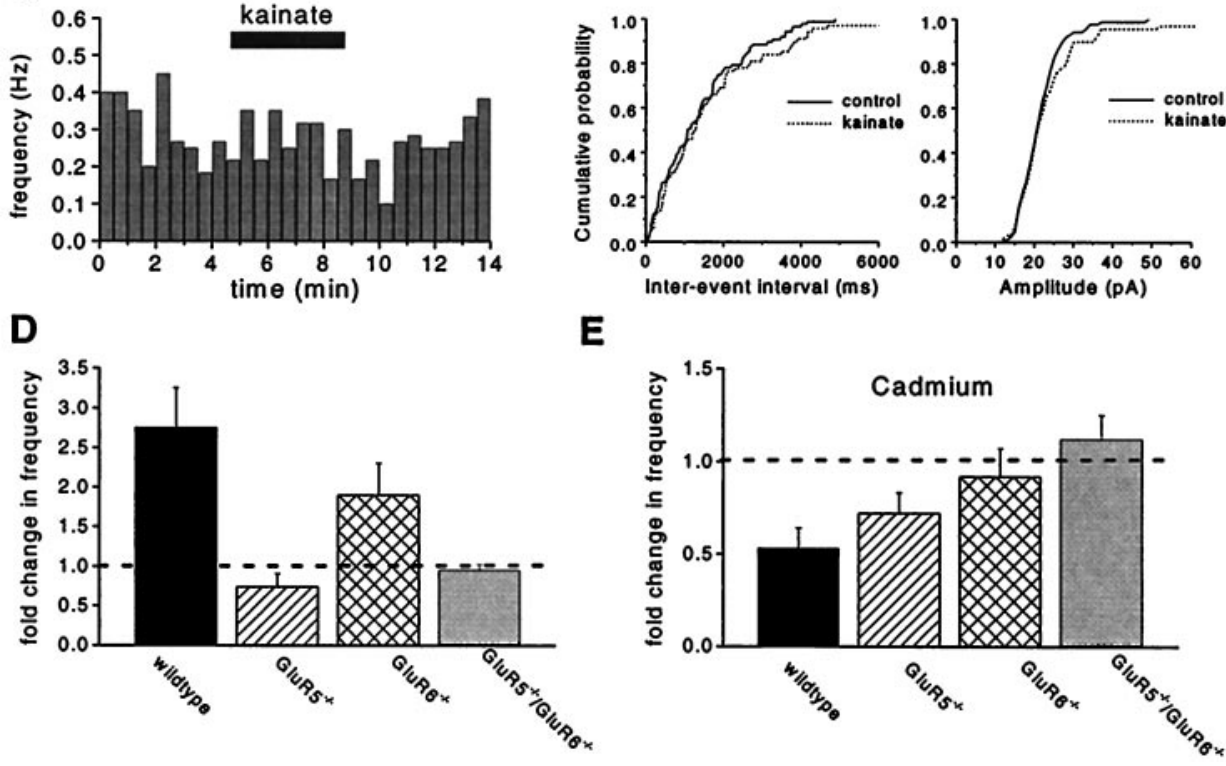

E

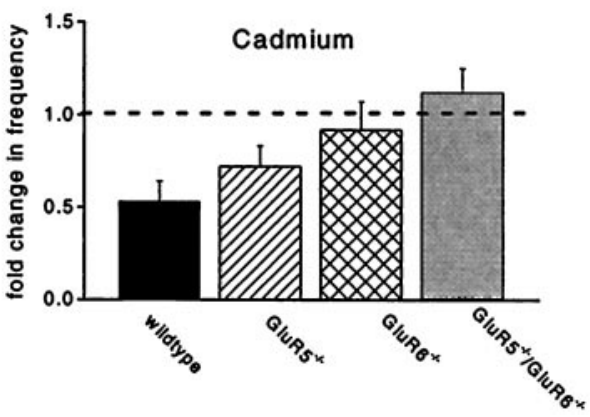

which can coassemble to form receptors with distinct characteristics (Cui and Mayer, 1999). Indeed, ATPA has been shown to activate heteromeric GluR5/GluR6 and GluR6/KA-2 receptors (Paternain et al., 2000). Although formally possible, our results would require that GluR5 $5^{-1-}$ subunits be essentially nonf unctional in the absence of a GluR6 subunit; furthermore, the absence of GluR5 subunits from such a heteromeric assembly would make little difference in the action of presynaptic kainate receptors. Our observation that kainate reduced MF EPSC amplitudes in GluR5 $5^{-1-}$ mice, but not GluR6 ${ }^{-/-}$or GluR5 ${ }^{-1-} / \mathrm{GluR6}^{-/-}$ mice, supports the interpretation that in mice GluR6 is the critical subunit that comprises the presynaptic MF kainate receptor and is consistent with the high levels of expression of GluR6 mRNA in the dentate gyrus (Bahn et al., 1994; Bureau et al., 1999).

Previous research also supports the existence of presynaptic kainate receptors on (or near) CA3 axon terminals, because kainate receptor activation was shown to inhibit excitatory transmission at A-C $\rightarrow$ CA3 synapses (Bortolotto et al., 1999). As with MF transmission, we found that kainate receptors containing GluR6 subunits mediate this suppression of transmission at collateral synapses.

\section{Kainate receptor-mediated potentiation of synaptic transmission}

In contrast to MF and A-C inputs, perforant path EPSC amplitudes were increased and failures were decreased after activation of kainate receptors. We found that both GluR5 and GluR6 subunits contributed to the increase in PP stimulus-evoked transmission. In addition to an increase in EPSC amplitude at the PP, we also observed a decrease in synaptic failures. This is suggestive of a presynaptic change in release probability; conversely, the perforant path paired-pulse ratio, which would be predicted to decrease with an increased release probability, did not change during kainate application. However, in a number of studies the paired-pulse ratio was shown not to be correlated with changes in vesicular release probability (Alger et al., 1996; Glitsch and Marty, 1999). Furthermore, we cannot exclude the possibility that activation of kainate receptors potentiates perforant path transmission via a postsynaptic mechanism. Perforant path EPSPs were shown to be amplified by voltage-gated calcium and sodium conductances (Urban et al., 1998). Although voltage-dependent sodium channels were blocked 
by inclusion of QX-314 in our internal solution, it is conceivable that postsynaptic calcium channels involved in perforant path EPSC propagation to the soma were modulated by kainate receptor activation. Therefore, kainate may affect perforant path transmission via multiple mechanisms at the nerve terminal, axons, or the postsynaptic dendrites.

\section{Presynaptic kainate receptors increase action potential- independent glutamate release}

Although a previous report did not find a kainate-mediated change in mEPSC frequency in guinea pigs (Castillo et al., 1997), because of the effects of kainate receptor activation on evoked EPSCs we tested whether mEPSC frequencies might be affected in our recordings. We found that in a subset of neurons mEPSC frequencies were increased after activation of kainate receptors; this increase arose from activation of receptors incorporating the GluR5 subunit. Although it is not possible to identify the synaptic source of the mEPSCs with any degree of certainty, the observed increase in frequency and the dependence on GluR5 subunits supports the hypothesis that kainate effects on mEPSC frequency occurred primarily at perforant path synapses. The GluR5 receptordependent increase in mEPSC frequency was entirely occluded in the presence of the nonselective $\mathrm{Ca}^{2+}$ channel blocker cadmium. Rather, in the presence of cadmium we observed a small depression of mEPSC frequency in neurons from wild-type and GluR5 ${ }^{-1-}$ mice that was not observed in the GluR6 ${ }^{-1-}$ or GluR5 ${ }^{-1-} /$ GluR6 $^{-/-}$knock-out mice, suggesting that the GluR6 receptor subunit underlay this effect. The fact that these kainate receptors mediate opposing actions on mEPSC frequency suggests that they are coupled to different signaling systems within the presynaptic nerve terminals. The GluR5 receptor-mediated increase in frequency may be explained by a receptor-mediated presynaptic depolarization of the nerve terminal that results in activation of voltage-sensitive, $\mathrm{Cd}^{2+}$-sensitive calcium channels. After block of this pathway, a GluR6-mediated depression of release is observed that is independent of $\mathrm{Ca}^{2+}$ channel activation.

The objective of this study was to use gene-targeted mice to determine the receptor subunits that underlie kainate-mediated modulation of CA3 excitatory transmission; consequently, we have not explored the physiological conditions that might activate presynaptic kainate receptors. However, these are questions that are integral to understanding the physiological and pathological significance of kainate receptors. It is unlikely that these receptors will be activated to a degree equivalent to bath application of kainate during normal brain function, and it is probable that activation of terminal or axonal kainate receptors by endogenous glutamate will have less dramatic effects on synaptic transmission. Studies comparing the characteristics of excitatory transmission in wild-type and kainate receptor knock-out mice, particularly during short- and long-term plasticity paradigms, will further clarify the function of these receptors.

Recently it was shown that kainate receptors are necessary for induction of long-term potentiation; these studies again relied on an antagonist presumed selective for GluR5 kainate receptors (Bortolotto et al., 1999). Regardless of the receptor composition, however, the results from Bortolotto et al. (1999) suggest that kainate receptors play an important role in the physiology of the mossy fiber synapse. Whether the kainate receptors involved in long-term potentiation (LTP) are located presynaptically or in fact mediate induction of LTP from a postsynaptic locus remains to be established (Zalutsky and Nicoll, 1990; Yeckel et al., 1999). Our data and those of previous studies have established that kainate receptors are present on axons or terminals and could modulate synaptic transmission onto CA3 neurons.

In this study we show that kainate receptors act via heterogeneous mechanisms to modulate excitatory transmission to CA3 pyramidal neurons. We have made use of kainate receptor knock- out mice to reveal which subunits are involved in these effects. Our data support the hypothesis that kainate receptors act by regulating excitatory synaptic transmission in the CA3 region and thus may be of critical importance in hippocampal function.

\section{REFERENCES}

Alger BE, Pitler TA, Wagner JJ, Martin LA, Morishita W, Kirov SA, Lenz RA (1996) Retrograde signalling in depolarization-induced suppression of inhibition in rat hippocampal CA1 cells. J Physiol (Lond) 496:197-209.

Amaral DG, Witter MP (1989) The three-dimensional organization of the hippocampal formation: a review of anatomical data. Neuroscience 31:571-591.

Bahn S, Volk B, Wisden W (1994) Kainate receptor gene expression in the developing rat brain. J Neurosci 14:5525-5547.

Ben-Ari Y (1985) Limbic seizure and brain damage produced by kainic acid: mechanisms and relevance to human temporal lobe epilepsy. Neuroscience 14:375-403.

Berzhanskaya J, Urban NN, Barrionuevo G (1998) Electrophysiological and pharmacological characterization of the direct perforant path input to hippocampal area CA3. J Neurophysiol 79:2111-2118.

Bortolotto ZA, Clarke VRJ, Delany CM, Parry MC, Smolders I, Vignes M, Ho KH, Miu P, Brinton BT, Fantaske R, Ogden A, Gates M, Ornstein PL, Lodge D, Bleakman D, Collingridge GL (1999) Kainate receptors are involved in synaptic plasticity. Nature 402:297-301.

Brickley S, Swanson GT, Contractor A, Farrant M, Sailer A, Cull-Candy SG, Heinemann SF (1999) Functional GluR5-containing kainate receptors are restricted to extrasynaptic sites in Purkinje cells of the mouse cerebellum. J Physiol (Lond) 521:90P.

Bureau I, Bischoff S, Heinemann SF, Mulle C (1999) Kainate receptormediated responses in the CA1 field of wild-type and GluR6-deficient mice. J Neurosci 19:653-663.

Castillo PE, Malenka RC, Nicoll RA (1997) Kainate receptors mediate a slow postsynaptic current in hippocampal CA3 neurons. Nature 388:182-186.

Chittajallu R, Vignes M, Dev KK, Barnes JM, Collingridge GL, Henley JM (1996) Regulation of glutamate release by presynaptic kainate receptors in the hippocampus. Nature 379:78-81.

Chittajallu R, Braithwaite SP, Clarke VR, Henley JM (1999) Kainate receptors: subunits, synaptic localization and function. Trends Pharmacol Sci 20:26-35.

Clarke VR, Ballyk BA, Hoo KH, Mandelzys A, Pellizzari A, Bath CP, Thomas J, Sharpe EF, Davies CH, Ornstein PL, Schoepp DD, Kamboj RK, Collingridge GL, Lodge D, Bleakman D (1997) A hippocampal GluR5 kainate receptor regulating inhibitory synaptic transmission. Nature 389:599-603.

Cossart R, Esclapez M, Hirsch JC, Bernard C, Ben-Ari Y (1998) GluR5 kainate receptor activation in interneurons increases tonic inhibition of pyramidal cells. Nat Neurosci 1:470-478.

Cui C, Mayer ML (1999) Heteromeric kainate receptors formed by the coassembly of GluR5, GluR6, and GluR7. J Neurosci 19:8281-8291.

Dingledine R, Borges K, Bowie D, Traynelis SF (1999) The glutamate receptor ion channels. Pharmacol Rev 51:7-61.

Frerking M, Nicoll RA (2000) Synaptic kainate receptors. Curr Opin Neurobiol 10:342-351.

Frerking M, Malenka RC, Nicoll RA (1998) Synaptic activation of kainate receptors on hippocampal interneurons. Nat Neurosci 1:479-486.

Frerking M, Petersen CC, Nicoll RA (1999) Mechanisms underlying kainate receptor-mediated disinhibition in the hippocampus. Proc Natl Acad Sci USA 96:12917-12922.

Glitsch M, Marty A (1999) Presynaptic effects of NMDA in cerebellar Purkinje cells and interneurons. J Neurosci 19:511-519.

Hollmann M, Heinemann S (1994) Cloned glutamate receptors. Annu Rev Neurosci 17:31-108.

Kamiya H, Ozawa S (1998) Kainate receptor-mediated inhibition of presynaptic $\mathrm{Ca}^{2+}$ influx and EPSP in area CA1 of the rat hippocampus. J Physiol (Lond) 509:833-845.

Kamiya H, Ozawa S (2000) Kainate receptor-mediated presynaptic inhibition at the mouse hippocampal mossy fibre synapse. J Physiol (Lond) 523:653-665.

Kamiya H, Shinozaki H, Yamamoto C (1996) Activation of metabotropic glutamate receptor type 2/3 suppresses transmission at rat hippocampal mossy fibre synapses. J Physiol (Lond) 493:447-455.

Macek TA, Winder DG, Gereau IV RW, Ladd CO, Conn PJ (1996) Differential involvement of group II and group III mGluRs as autoreceptors at lateral and medial perforant path synapses. J Neurophysiol 76:3798-3806.

Manabe T, Wyllie DJ, Perkel DJ, Nicoll RA (1993) Modulation of synaptic transmission and long-term potentiation: effects on paired pulse facilitation and EPSC variance in the CA1 region of the hippocampus. J Neurophysiol 70:1451-1459. 
Mulle C, Sailer A, Pérez-Otano I, Dickinson-Anson H, Castillo PE, Bureau I, Maron C, Gage FH, Mann JR, Bettler B, Heinemann SF (1998) Altered synaptic physiology and reduced susceptibility to kainateinduced seizures in GluR6-deficient mice. Nature 392:601-605.

Mulle C, Sailer A, Swanson GT, Brana C, O'Gormon S, Bettler B, Heinemann SF (2000) Subunit composition of kainate receptors in hippocampal interneurons. Neuron, in press.

Paternain AV, Herrera MT, Nieto MA, Lerma J (2000) GluR5 and GluR6 kainate receptor subunits coexist in hippocampal neurons and coassemble to form functional receptors. J Neurosci 20:196-205.

Rodriguez-Moreno A, Herreras O, Lerma J (1997) Kainate receptors presynaptically downregulate GABAergic inhibition in the rat hippocampus. Neuron 19:893-901.

Steward O (1976) Topographic organization of the projections from the entorhinal area to the hippocampal formation of the rat. J Comp Neurol 167:285-314.

Urban NN, Henze DA, Barrionuevo G (1998) Amplification of perforant- path EPSPs in CA3 pyramidal cells by LVA calcium and sodium channels. J Neurophysiol 80:1558-1561.

Vignes M, Collingridge GL (1997) The synaptic activation of kainate receptors. Nature 388:179-182.

Vignes M, Clarke VR, Parry MJ, Bleakman D, Lodge D, Ornstein PL, Collingridge GL (1998) The GluR5 subtype of kainate receptor regulates excitatory synaptic transmission in areas CA1 and CA3 of the rat hippocampus. Neuropharmacology 37:1269-1277.

Xiang Z, Brown TH (1998) Complex synaptic current waveforms evoked in hippocampal pyramidal neurons by extracellular stimulation of dentate gyrus. J Neurophysiol 79:2475-2484.

Yeckel MF, Kapur A, Johnston D (1999) Multiple forms of LTP in hippocampal CA3 neurons use a common postsynaptic mechanism. Nat Neurosci 2:625-633.

Zalutsky RA, Nicoll RA (1990) Comparison of two forms of long-term potentiation in single hippocampal neurons. Science 248:1619-1624. 